\title{
OSAS AND ASSOCIATED COMORBIDITIES - A RETROSPECTIVE STUDY
}

\author{
Jeler Elena-Corina \\ Elias University Hospital, Bucharest \\ elenajeler@yahoo.com
}

\begin{abstract}
OSAS (obstructive sleep apnoea syndrome) is the most common type of sleep apnoea, characterised by obstruction of the upper airways during sleep, causing the absence or reduction of airflow, although there is respiratory muscular activity. It contributes to the occurrence of multiple complications such as hypertension, obesity, diabetes mellitus, cardiac and cerebral pathology, metabolic damage. The objective of this study was to evaluate the major comorbidities associated with OSAS in a group of 101 clinically diagnosed and polysomnographic patients with OSAS at "Marius Nasta" Institute in Bucharest during 20142015. The obtained results revealed a very high prevalence of ENT disorders, hypertension, dyslipidaemia and gastroesophageal reflux. Also, among these patients, there was an increased incidence of rhythm disorders (17.8\%), such as RBB, ESSV, FiA, but also of ischaemic heart disease (16.83\%).
\end{abstract}

Keywords: OSAS, PAP, HTA, comorbidities

\section{Rezumat}

SASO (sindrom de apnee în somn forma obstructivă) este cel mai frecvent tip de apnee în somn, caracterizat de obstrucția căilor respiratorii superioare în timpul somnului, determinând absența sau reducerea fluxului aerian, deși există activitatea musculaturii respiratorii. Aceasta contribuie la apariția multiplelor complicații, cum ar fi hipertensiunea arterială, obezitatea, diabetul zaharat, patologia cardiacă și cerebrală, afectarea metabolică. Obiectivul acestui studiu a fost evaluarea comorbidităților majore asociate SASO la un grup de 101 de pacienți diagnosticați clinic și polisomnografic cu SASO în cadrul Institutului Marius Nasta din București în perioada 2014-2015. Rezultatele obținute au evidențiat prevalența foarte ridicată a afecțiunilor ORL, a hipertensiunii arteriale, a dislipidemiei și a refluxului gastroesofagian. De asemenea, în rândul acestor pacienți a fost semnalată existența crescută a tulburărilor de ritm, (17,8\%), precum BRD, ESSV, FiA, dar și a bolii cardiace ischemice (16,83\%).

Cuvinte cheie: SASO, PAP, HTA, comorbidități. 


\section{INTERNAL}

\section{Original papers}

\section{General notions}

Obstructive sleep apnoea syndrome (OSAS) is an impairment belonging to respiratory disorders occurring during sleep, with a prevalence of $4-6 \%$ of the population. OSAS is characterised by the existence of multiple respiratory obstructive episodes occurring during sleep resulting in the absence or reduction of air flow. The diagnosis of OSAS presupposes at least 5 respiratory pauses within an hour of sleep, lasting at least 10 seconds ${ }^{(1)}$.

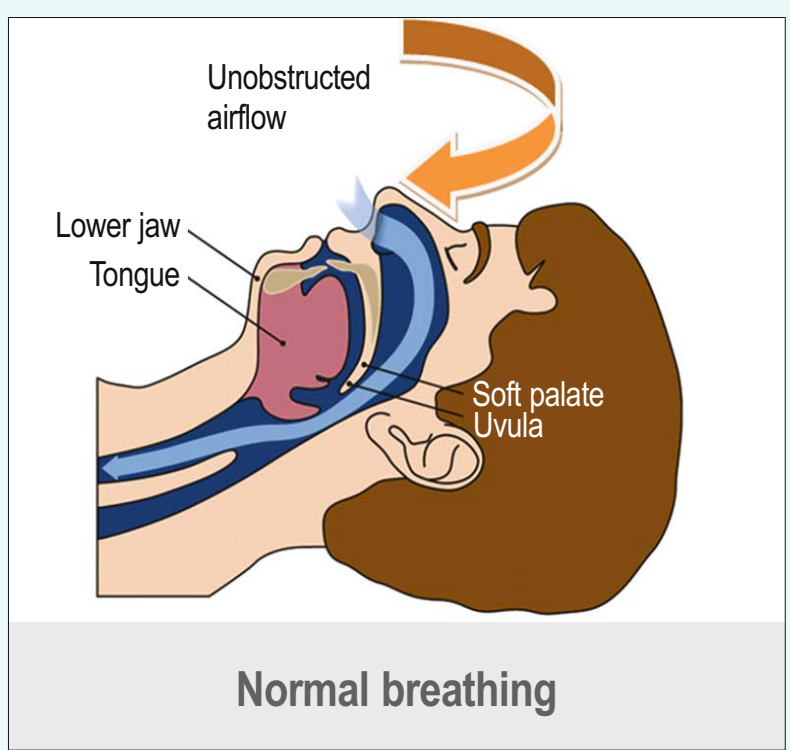

OSAS arises from the presence of more than one etiologic factor, the most important factor being the reduction in size of the airways, which occurs through the hypertrophy of the tonsils, the tongue and
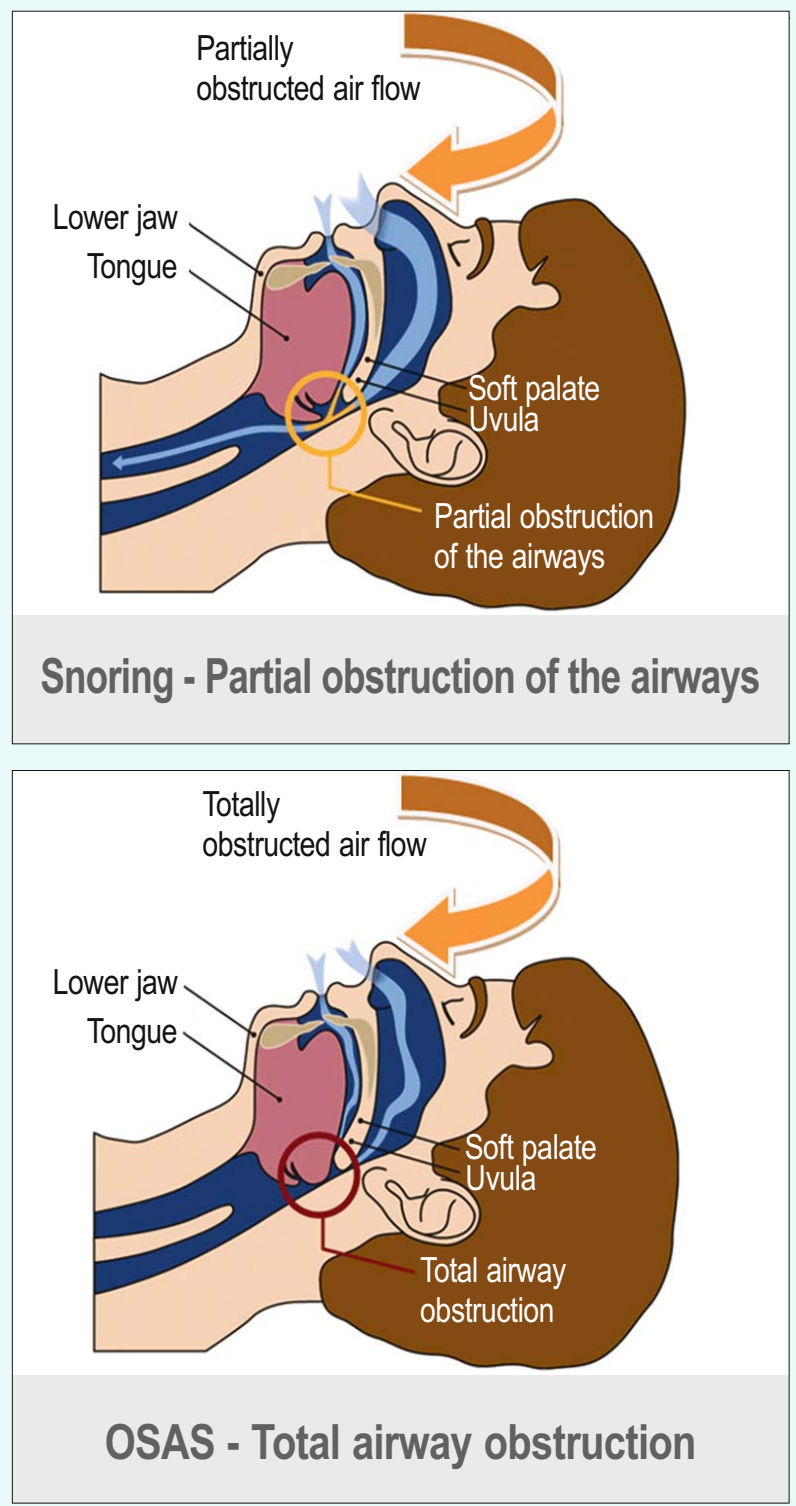

Figure 1 . Air flow during normal breathing during sleep and within OSAS ${ }^{(2)}$

The existence of these pathologies prevents the normal passage of the air flow, causing the collapse of the airways. With the 
repeated occurrence of airway collapse, traumatization of the airways occurs, as evidenced by the objection of the histopathological changes of the pharyngeal muscle fibres ${ }^{(5)}$.

During sleep, the activity of the airway dilator muscles decreases, leading to their collapse ${ }^{(6)}$. In addition, the existence of cranio-facial anomalies determined additional reduction in the activity of the genioglossus muscle, thus increasing the risk of OSAS. At the beginning of the apnoea episode, the phasic contraction of the airway dilator muscles is minimal, requiring additional contraction of these muscles to prevent airway collapse ${ }^{(7)}$. The microawakenings, which define the end of the apnoea episode, increase the dilator muscle tone in the neck, thus restoring upper airway permeability and ventilation ${ }^{(8)}$.

High frequency of OSAS was observed among patients with congenital diseases and
Pierre-Robin syndrome, Down syndrome, Marfan syndrome, achondroplasia, which include the existence of craniofacial anomalies. Pierre-Robin Syndrome is characterised by micrognatics, glossoptosis, cleft palate ${ }^{(9)}$. In Down syndrome, there is evidence of hypoplasia of the middle part of the face, amygdala hypertrophy and macroglossia. In these craniofacial changes, repeated respiratory infections, chronic rhinitis, but also the existence of gastroesophageal reflux, which causes oedema in the posterior wall of the pharyn $x^{(10)}$ also contribute to the occurrence of airway collapse. Marfan syndrome describes craniofacial changes such as dolichocephaly, retrogression, macrocephaly, and increased airway resistance due to increased laxity characteristic of this condition. In achondroplasia, autosomal dominant disease, patients present the prominence of

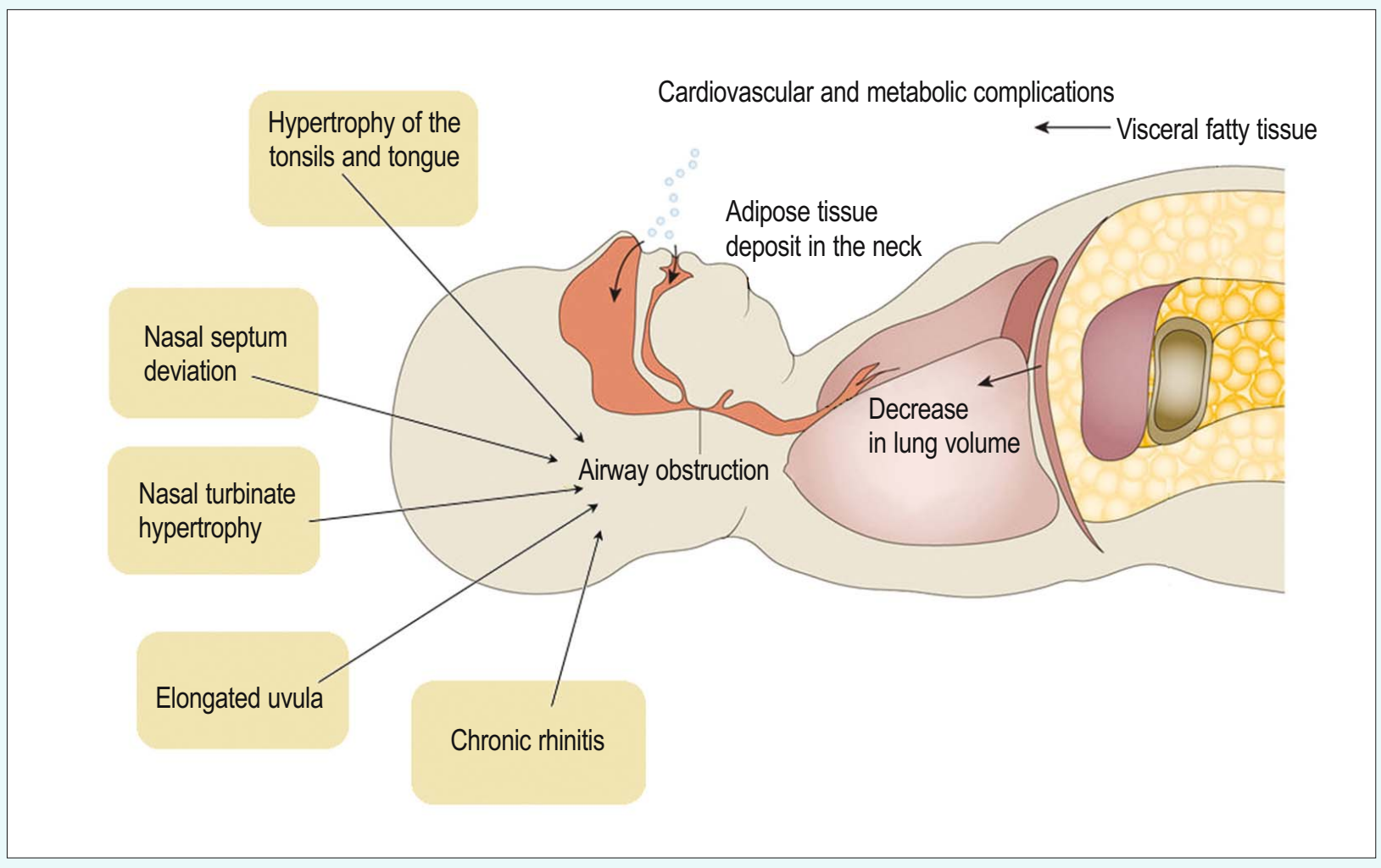

Figure 2. Etiologic factors influencing OSAS ${ }^{(4)}$ 


\section{INTERNAL}

\section{Original papers}

the frontal bones, the mid-sized hypoplasia of the face, the nasal rooting collapse, along with the thickening of the mandible ${ }^{(11,12,13)}$ elements that contribute to the increased risk of OSAS occurrence.

In acromegaly and untreated hypothyroidism, the existence of macroglossia, along with the regrowth of pharyngeal tissues by deposition of mucopolysaccharides, and by the existence of central myopathy and obesity, contributes to an increase in the risk of OSAS occurrence ${ }^{(14)}$.

Last but not least, we should mention the frequency of psychiatric illnesses, such as depression, anxiety, bipolar disorder frequently manifested in OSAS ${ }^{(15)}$, slight depression being diagnosed in a high percentage, $62 \%$ of women with OSAS, and in men in a percentage of $39 \%{ }^{(16)}$.

All these complications arising in the context of patients with OSAS reveal increased importance of early diagnosis of patients with OSAS, to impose adequate treatment. The treatment with PAP has an important role, demonstrating its role in improving cardiac pathology but also in vascular accidents prevention.

OSAS predisposes to the occurrence of numerous respiratory, cardiovascular complications (ischaemic heart disease, heart failure, bradyarrhythmias and tachyarrhythmias, hypertension, myocardial infarction), gastroesophageal reflux, metabolic and endocrine disorders (type 2 diabetes mellitus, dyslipidaemia, thyroid dysfunction and gonadal dysfunction), sexual dynamic disorders, but also neuropsychiatric disorders, the most common being depression.

OSAS is a risk factor for the occurrence and progression of HBP, more than $50 \%$ of patients affected by OSAS being diagnosed with hypertension ${ }^{(17,18)}$. The presence of OSAS has to be suspected in every patient presenting treatment-resistant $\mathrm{HBP}$, as well as to individuals exceeding by $120 \%$ their ideal weight ${ }^{(19)}$. Treatment-resistant HBP is defined by the persistence of blood pressure increase over $140 / 90 \mathrm{mmHg}$ during treatment with three antihypertensives used in maximum dose ${ }^{(20)}$, OSAS being diagnosed in $83 \%$ of patients presenting resistant HBP. The occurrence of HBP in patients who are diagnosed with OSAS is explained by repeated episodes of apnoea, causing repeated bouts of hypoxemia, determining oxidative stress increase, emergence of atherosclerotic lesions, which, alongside the association with procoagulant status, determine the occurrence of vascular lesions ${ }^{(21)}$.

The conducted clinical trials highlighted very high values of $240 / 130 \mathrm{mmHg}$ at the end of the episode, due to vasoconstriction occurring by increasing the activity of the 
sympathetic system ${ }^{(17)}$. Also, studies revealed that the incidence of hypertension is increased in proportion to the severity of OSAS, along with the fact that the therapeutic effectiveness of HBP is better in patients with slight and medium OSAS ${ }^{(22)}$.

Between OSAS and strokes, there is a close relationship, OSAS being described as a risk factor for the occurrence of strokes, and if the patient also experiences rhythm disorders, such as atrial fibrillation, then the risk of the patient to suffer a stroke is much higher ${ }^{(23)}$, OSAS being described at $77 \%$ of men, i.e. $64 \%$ of women with stroke ${ }^{(24)}$. This is possible because in OSAS cerebral blood flow is reduced $^{(25)}$. The repeated episodes of nocturnal hypoxemia occurring in OSAS cause vascular changes both by vasoconstriction and by decreasing the effectiveness of vascular protection agents $^{(26)}$. The risk of patients with strokes to develop OSAS is increased in the first 24 hours after the stroke, when adopting the supine position, the patient presents the upper airway collapse ${ }^{(27)}$, this risk being maintained high also 1 year after the stroke ${ }^{(28,29)}$, describing a direct relationship between the severity of these two disorders. In OSAS, more than $50 \%$ of patients exhibit cardiac arrhythmias during sleep, the most common being atrial fibrillation, ventricular tachycardia, type 2 atrioventricular block, premature ventricular contractions ${ }^{(17)}$, describing a direct proportional relationship between the severity of OSAS and occurrence of these arrhythmias. These arrhythmias occur due to hypoxemia, hypercapnia, acute atrial dilation, negative intrathoracic pressure, causing progressive damage in the filling of the left ventricle ${ }^{(30)}$. During sleep, the airway obstruction will increase the oxygen demand of myocardium during the apnoea episode and, in conjunction with the degree of hypoxemia, it will lead to the occurrence of myocardial ischaemia due to the occurrence of negative intrathoracic pressure, thus increasing the transmural gradient in the ventricle. The occurrence of myocardial ischaemia in OSAS is also explained by increasing the sympathetic activity, which, along with hypoxemia and hypercapnia, will cause an increase in blood pressure and heart rate ${ }^{(21)}$, thus explaining the high percentage of OSAS in patients with $65.7 \% \mathrm{IMA}^{(31)}$. The OSAS treatment has a high clinical importance, specifically the use of PAP, with a lesser degree of recurrence of arterial fibrilation, being $42 \%$ in patients who use PAP, compared to $82 \%$ in patients with OSAS, but who do not use PAP(30).

Last but not least OSAS determines increases in the risk of sudden death especially during sleep, the risk being higher as the degree of severity of OSAS is higher ${ }^{(32)}$, this being due to increased sympathetic activity, to increased blood pressure, along with hypoxemia and hypercapnia occurred during the apnoea episode ${ }^{(33)}$.

For the patients diagnosed with severe OSAS, 1 in 3 patients present nocturnal angina pectoris and ST-segment depression, clinical trials showing an improvement in patients who follow treatment with PAP $^{(17)}$. Also, studies highlighted high prevalence of about $10 \%$ for pulmonary hypertension among patients with OSAS, treatment with PAP relieving pulmonary artery pressure having a very important role ${ }^{(17)}$.

Clinical trials demonstrated the high frequency of metabolic disorders, such as dyslipidemia, insulin resistance, low glucose tolerance and type 2 diabetes mellitus ${ }^{(34)}$ among patients with OSAS, and the positive effect of treatment with PAP, emphasising once again the need for prompt and 


\section{INTERNAI}

\section{Original papers}

appropriate treatment of OSAS. OSAS is diagnosed in a percentage of $40-60 \%$ among patients with chronic kidney disease, which increases morbidity and mortality in these patients. One factor is uraemia, determining increases in the level of airway oedema, which determines their collapse. Thus, treating aggressive kidney disease by night dialysis will reduce the airway edema, thus improving SASO.

In patients with acute or chronic rhinitis, we encounter increased nasal resistance especially when these patients adopt the supine position, recognising these symptoms as being of therapeutic importance because the use of nasal decongestants leads to the reduction of supraglottic resistance, thus having a role in improving the clinical symptomatology of patients $^{(35,36)}$.

\section{Materials and working methods}

In the "Marius Nasta" Institute of Pneumology, 101 patients were assessed from the moment of diagnosis with OSAS, the latter being investigated as regards the associated comorbidities. At the beginning of the study, each patient signed the informed consent which allowed me use to use personal data. Furthermore, the Commission of Ethics of the "Marius Nasta" Institute of Pneumology in Bucharest approved this study, data being processed using Excel program.

\section{Obtained results}

From the point of view of comorbidities associated with OSAS, a high percentage of patients with dyslipidemia (55.44\%), gastroesophageal reflux (36.63\%), diabetes mellitus $(19.8 \%)$, strokes $(10.9 \%)$ was noticed. Within the cardiovascular disorders, hypertension was most commonly present, being diagnosed at $82.17 \%$ of these patients, followed by rhythm disorders $17.8 \%$ and ischaemic heart disease $16.83 \%$. As a result of ENT examination, most patients were diagnosed with nasal septum deviation $(62.37 \%)$, the second place being macroglossia (44.55\%). Other ENT-related diseases identified in patients included in this study were the existence of a narrow isthmus (36.63\%), hypertrophy of nasal turbinates $(24.75 \%)$, elongated uvula (21.78\%).

\section{Conclusions}

OSAS is associated with different comorbidities predisposing or, usually, associated with it. All this indicates the need for meticulous investigation of the patient to promptly detect comorbidities and risk factors, recommending the examination of 


\begin{tabular}{|c|c|c|}
\hline \multicolumn{2}{|c|}{ Diseases } & Total \\
\hline \multirow{3}{*}{ Endocrine } & Tumours & 2 \\
\hline & Hypothyroidism & 5 \\
\hline & Hyperthyroidism & 2 \\
\hline \multirow{2}{*}{ Diabetes mellitus } & Type 1 & 1 \\
\hline & Type 2 & 19 \\
\hline \multicolumn{2}{|c|}{ Dyslipidemia } & 56 \\
\hline \multirow{2}{*}{ Pulmonary disorders } & Bronchial asthma & 4 \\
\hline & COPD & 16 \\
\hline \multicolumn{2}{|c|}{ Gastroesophageal reflux disease } & 37 \\
\hline Neurological diseases & Ischaemic stroke & 11 \\
\hline \multirow{3}{*}{ Rhythm disorders } & RBB & 5 \\
\hline & ESSV & 4 \\
\hline & $\mathrm{FiA}$ & 9 \\
\hline \multirow{4}{*}{ HBP } & Normally high & 10 \\
\hline & Stage 1 & 40 \\
\hline & Stage 2 & 19 \\
\hline & Stage 3 & 14 \\
\hline \multicolumn{2}{|c|}{ Ischaemic coronary artery disease } & 17 \\
\hline \multirow{12}{*}{ ENT disorders } & Septum deviation & 63 \\
\hline & Chronic rhinitis & 31 \\
\hline & Chronic sinusitis & 6 \\
\hline & Elongated uvula & 22 \\
\hline & $\begin{array}{c}\text { Tonsillar } \\
\text { hypertrophy }\end{array}$ & 21 \\
\hline & $\begin{array}{l}\text { Hypertrophic } \\
\text { turbinates }\end{array}$ & 25 \\
\hline & Macroglossia & 45 \\
\hline & Narrow isthmus & 37 \\
\hline & Prolabated palate & 19 \\
\hline & $\begin{array}{c}\text { Oedema of vocal } \\
\text { cord }\end{array}$ & 1 \\
\hline & Pillar hypertrophy & 12 \\
\hline & Nasal polyposis & 10 \\
\hline
\end{tabular}




\section{INTERNAL}

Original papers

the patient during the admission. In this regard there is a need for close collaboration between the pulmonologist, cardiologist, neurologist, ENT specialist, both in the diagnosis and treatment of this disorder, especially with PAP, alleviating both OSAS and its comorbidities.

\section{Bibliography}

1. "The International Classification Of Sleep Disorders, Revised Diagnostic and Coding Manual". Produced by the American Academy of Sleep Medicine in association with the European Sleep Research Society, Japanese Society Of Sleep, Research Latin American Sleep Society, 2001, pp.52-58.

2. http://www.carmipharmacy.com/services/sleepapnea/ - accesat la date de 01.03.2018.

3. Wellman $A$, et al. "Ventilatory control and airway anatomy in obstructive sleep apnoea. Am J Respir Crit Care Med. 2004;170:1225-1232.

4. Patrick A Lévy, et al. Obstructive sleep apnoea syndrome. Nature Reviews Disease Primers. (2015). 1. 10.1038/nrdp.2015.24.

5. Susheel P. Patil, et al. "Adult Obstructive Sleep Apnea Pathophysiology and Diagnosis" Chest. 2007 Jul; 132(1): 325.

6. Fogel RB, et al. "The effect of sleep onset on upper airway muscle activity in patients with sleep apnoea versus controls." J Physiol. 2005;564:549-562.

7. Strohl KP. "Upper airway muscles of respiration." Am Rev Respir Dis, 1981; 124: 211-213.

8. Fogel RB, et al. Sleep. 2: pathophysiology of obstructive sleep apnoea/hypopnoea syndrome. Thorax 2004;59:159-163.

9. Cole $A$; et al. "A new grading of Pierre Robin sequence." Cleft Palate Craniofac J. 2008; 45(6):603-6.

10. Sally R. Shott. "Obstructive Sleep Apnea in Children with Down Syndrome: Why does my child need a sleep

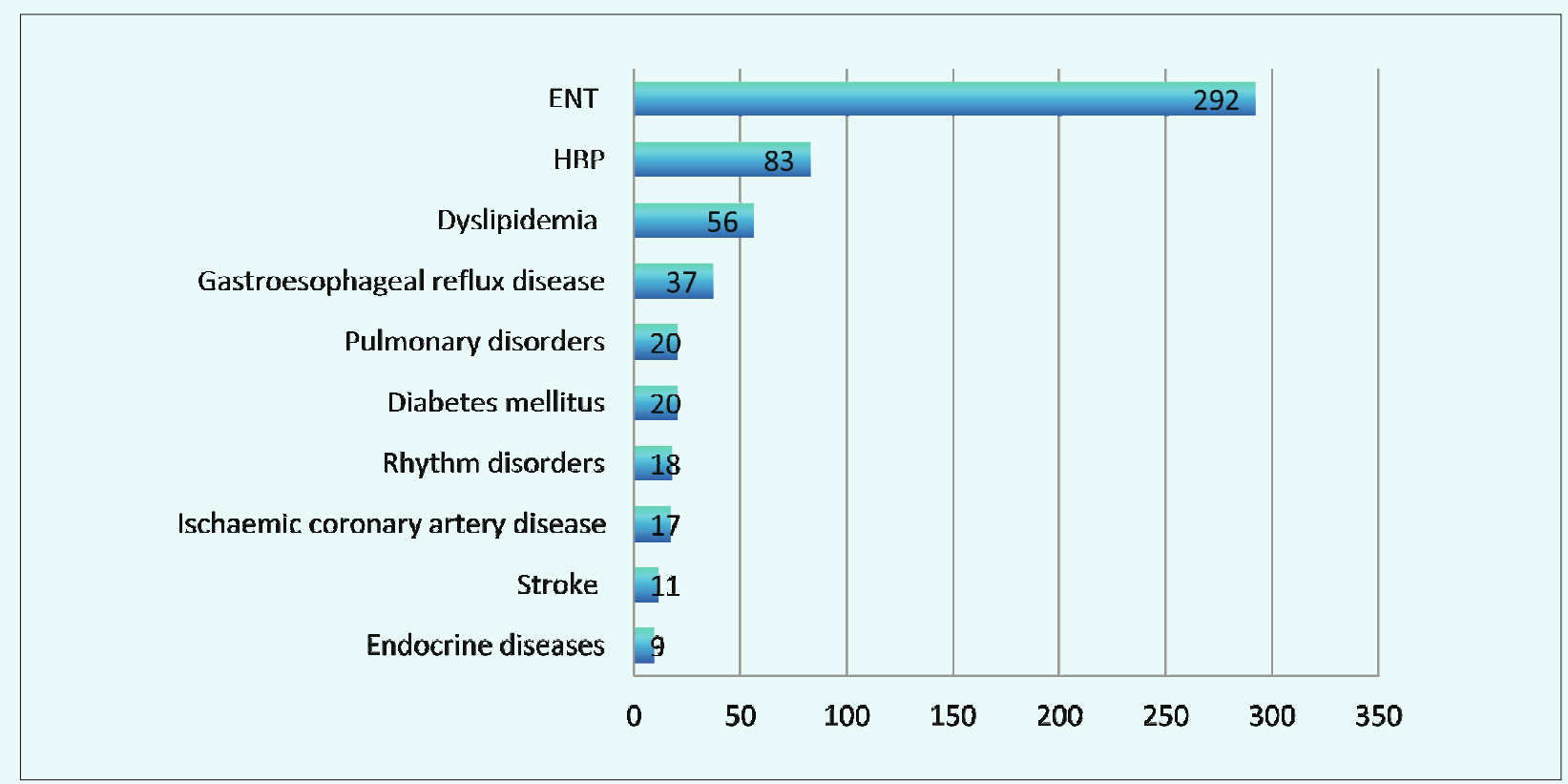

Figure 4. Prevalence of comorbidities in OSAS in the study batch 
study?." Cincinnati Children's Hospital University of Cincinnati Department of Otolaryngology Head and Neck Surgery.

11. Trotter TL, Hall JG. "Health supervision for children with achondroplasia." Pediatrics. 2005 Sep; 116(3):77183. Erratum in: Pediatrics. 2005 Dec;116(6):1615.

12. Wright MJ, Irving MD. "Clinical management of achondroplasia." Arch Dis Child. 2012 Feb;97(2):12934.

13. Vajo $Z$, et al. "The molecular and genetic basis of fibroblast growth factor receptor 3 disorders: the achondroplasia family of skeletal dysplasias, Muenke craniosynostosis, and Crouzon syndrome with acanthosis nigricans." Endocr Rev. 2000 Feb;21(1):2339. Review.

14. Mary Ann Yantis; Jacquelin Neatherlin. "Obstructive Sleep Apnea in Neurological Patients." J NeurosciNurs. 2005;37(3):150-155.

15. Sharafkhaneh $A$, et al. "Association of psychiatric disorders and sleep apnoea in a large cohort." Sleep. 2005; 28(11):1405-1411.

16. McCall W, et al. "Correlates of depressive symptoms in patients with obstructive sleep apnoea." J Clin Sleep Med. 2006;2:424-6.

17. Virend K. Somers, et al. "Sleep Apnea and Cardiovascular Disease." Journal of the American College of CardiologyVol. 52, No. 8, 2008, pp.686-717, by the American Heart Association, Inc, and the American College of Cardiology Foundation, Published by ElsevierInc., doi:10.1016/j.jacc.2008.05.002.

18. Peppard PE, et al. "Prospective study of the association between sleep-disordered breathing and hypertension." N EnglJ Med. 2000;342:1378-1384.

19. Prisant $L M$, et al. "Obstructive sleep apnoea syndrome." J Clin Hypertens (Greenwich), 2006 Oct; 8(10):746-50.

20. Logan AG, et al. "High prevalence of unrecognized sleep apnoea in drug-resistant hypertension." J Hypertens. 2001;19: 2271-2277

21. Fernando De Torres-Alba, et al. "Obstructive Sleep Apnea and Coronary Artery Disease: From Pathophysiology to Clinical Implications." Pulmonary Medicine Volume 2013.

22. Lavie P, Hoffstein V. "Sleep apnoea syndrome: $\underline{a}$ possible contributing factor to resistant hypertension." Sleep. 2001;24:721-725.
23. Genevieve C Digby, Adrian Baranchuk. "Sleep Apnea and Atrial Fibrillation." 2012 Update Curr Cardiol Rev. 2012 Nov; 8(4): 265-272.

24. Dyken $M E$, et al. "Investigating the relationship between stroke and obstructive sleep apnoea." Stroke. 1996; 27: 401-407.

25. Foster GE, et al. "Effects of continuous positive airway pressure on cerebral vascular response to hypoxia in patients with obstructive sleep apnoea. "AmJ Respir Crit Care Med. 2007; 175: 720-725

26. Canessa N., et al. "Obstructive sleep apnoea: brain structural changes and neurocognitive function before and after treatment." American Journal of Respiratory and Critical Care Medicine. 2011;183(10):1419-1426.

27. Turkington PM, et al. "Prevalence and predictors of upper airway obstruction in the first 24 hours after acute stroke." Stroke. 2002; 33: 2037-2042

28. Palombini L, Guilleminault C. "Stroke and treatment with nasal CPAP." EurJ Neurol. 2006; 13: 198-200.

29. Sahlin C, et al. "Obstructive sleep apnoea is a risk factor for death in patients with stroke. "Arch Intern Med. 2008; 168: 297-301.

30. David Filgueiras-Rama, et al. "Arrhythmias in Obstructive Sleep Apnea: Underlying Mechanisms and Implications in the Clinical Setting. "Pulmonary Medicine Volume 2013.

31. Ludka O, et al. "Sleep apnoea prevalence in acute myocardial infarction--the Sleep Apnea in Post-acute Myocardial Infarction Patients (SAPAMI)." Study Int J Cardiol. 2014 Sep;176(1):13-9.

32. Gami AS., et al. "Day-night pattern of sudden death in obstructive sleep apnoea." N EnglJ Med. 2005 Mar 24; 352(12):1206-14.

33. Babak Mokhlesi, Naresh M. Punjabi. "REM-related" Obstructive Sleep Apnea: An Epiphenomenon or a Clinically Important Entity?" Sleep. 2012 Jan 1; 35(1): 5-7. 34. Ip MS, et al. "Obstructive sleep apnoea is independently associated with insulin resistance." Am J Respir Crit Care Med. 2002;165 (5):670-676

35. Anch AM, et al. "Supraglottic airway resistance in normal subjects and patients with occlusive sleep apnoea." J Appl Physiol: Respirat Environ Exercise Physiol 1982; 53: 1158-1163.

36. Lavie $P$, et al. "Breathing disorders in sleep associated with "microarousals' in patients with allergic rhinitis." Acta Otolaryngol. 1981 Nov-Dec;92(5-6):529-33 